\title{
EL VIRUS DE LA D.V.B. COMO AGENTE CONTAMINANTE EN CULTIVO DE TEJIDOS ANIMALES
}

\begin{abstract}
Víctor J. Vera $A^{\star}$, Jorge L. Parra $A^{\star *}$, Gloria C. Ramírez $\mathbf{N}^{\star}$, Luis C. Villamil*
El Pestisvirus que produce la Diarrea Viral Bovina (V.D.V.B.), ocasiona problemas reproductivos en el ganado vacuno y se encuentra ampliamente difundido en el país. La presencia de cepas no citopatogénicas del mismo, las cuales normalmente no se evidencian en los cultivos celulares contaminados con éste virus, han constituido un limitante para el establecimiento y mantenimiento de cultivos primarios y líneas celulares libres del V.D.V.B., para uso rutinario en actividades diagnósticas o investigativas. El suero fetal bovino (SFB) es la fuente usual de contaminación para los cultivos de tejidos animales, dadas las escasas previsiones para el control de su calidad, ya que la recolección y mercadeo del SFB se realiza con criterios artesanales y $\sin$ los debidos controles de calidad. Específicamente en el caso del V.D.V.B., se pueden presentar dos situaciones con el SFB: que contenga partículas virales o que posea niveles de anticuerpos contra el virus; en ambos casos se darán problemas en los procedimientos realizados con dichos sueros.
\end{abstract}

Con el fin de controlar las contaminaciones de los cultivos celulares con el VDVB, en el Postgrado de la Facultad de Medicina Veterinaria de la Universidad Nacional, se ha empleado la técnica de Inmunofluorescencia Indirecta (IFI) para detectarlas tanto, en el SFB como en diferentes cultivos celulares, obteniéndose para el SFB el $25.8 \%$ de positivos de un total de 32 muestras de diferentes orígenes y para los cultivos celulares el $42.8 \%$ de positivos de 28 lotes, procedentes de diferente origen animal y centros de investigación, resultados que son comparables con los obtenidos por otros laboratorios internacionales como el National Animal Diseases Laboratory (NADL) del Departamento de Agricultura de USA.

Dentro de las recomendaciones para la prevención y control del problema en laboratorios de diagnóstico e investigación médica y veterinaria, que empleen tecnologías relacionadas con manejo y mantenimiento de cultivos celulares, están las de implementar técnicas para la detección del virus como la IFI, la peroxidasa o la Inmunoprecipitación, al igual que el manejo de un bajo número de fetos en la conformación de lotes de SFB.

* Médico Veterinario, profesor P.R.A. U. Nal.

* Médico Veterinario, profesora P.R.A. U. Nal.

* Médico Veterinario, profesor P.R.A. U. Nal.

** Médico Veterinario, ICA, estudiante P.R.A. Facultad de Medicina Veterinariay de Zootecnia, Universidad Nacional de Colombia, Apartado 86957, Santafé de Bogotá. 


\section{INTRODUCCION}

Las experiencias obtenidas en el trabajo de laboratorio con agentes virales y los problemas, inquietudes y alternativas de solución que han surgido, evidencian la importancia del virus de la diarrea viral bovina (VDVB) como contaminante de cultivos celulares.

La patente interferencia del virus, supone dificultades en el diagnóstico, la investigación y la industria desarrollada en el campo Veterinario y tal vez en la investigación en el campo de la Medicina Humana.

El VDVB ocasiona el complejo Diarrea Viral Bovina-Enfermedad de las Mucosas, que afecta a los bovinos y a otros rumiantes, teniendo importancia en los bóvidos, por ser una limitante de salud que ocasiona en algunos casos, trastornos digestivos y respiratorios, y en otros, inmunodepresión y problemas reproductivos que se traducen en abortos momificaciones y mortalidad embrionaria. $(1,2)$.

El VDVB es ubicuo en el ganado bovino y está distribuido mundialmente con prevalencias serológicas promedio del 50\% (2), muy similares a las establecidas para el país en algunas áreas lecheras (3).

El VDVB es un virus ARN, del grupo de los Pestivirus de la familia Togaviridae, con dos biotipos, uno citopatogénico y el otro no citopatogénico, que se diferencian entre sí, por la presentación o ausencia de efecto citopático en cultivos celulares, no teniendo éste virus ninguna relación con los Rotavirus, productores de problemas digestivos tanto en el hombre como en diferentes especies domésticas como la bovina. ( 2 y 3 ).

La infección fetal con el VDVB, si se realiza antes de los 100 días de gestación (tiempo en el cual el feto no ha desarrollado un sistema inmune apto), conlleva a que el VDVB sea tomado como un componente propio, siendo inmunotolerante y portador del virus en la mayoría de los tejidos; pero si ésta se da después de este tiempo, en el feto o en el ternero al nacimiento, se puede aislar el virus y detectar la presencia de anticuerpos a la enfermedad, $(1,4)$.

\section{MATERIALES Y METODOS}

En esta comunicación se discuten aspectos relacionados con el VDVB, su distribución, los problemas que ocasiona y sus posibles soluciones, haciendo énfasis en las experiencias obtenidas en países desarrollados y en nuestro laboratorio en particular.

Se probaron 32 lotes de suero fetal bovino procedentes de diferentes usuarios del mismo (obtenidos por el PRA y laboratorios de Salud Humana, y comerciales).

Cada uno de los lotes fueron clarificados y esterilizados por filtración con membranas de 0.22 micras, fueron sometidos a prueba de esterilidad (siembra e incubación en agar sangre), inoculándose posteriormente al $10 \%$ en cultivos primarios libres de VDVB, los que fueron evaluados para el virus por Inmunofluorescencia Indirecta. Igualmente todos los sueros fueron titulados para el VDVB por la prueba de seroneutralización utilizando la cepa Singer (de referencia). (5).

También se evaluaron 28 lotes de cultivos celulares, tanto primarios como líneas de diferentes fuentes y células de mieloma, por IFI, para lo cual se realizaron micropreparados (laminillas) de cada uno de los lotes.

\section{RESULTADOS}

La experiencia en nuestro laboratorio con los sueros nacionales producidos por entidades comerciales que no cuentan con la infraestructura adecuada para garantizar su inocuidad, (así se certifique lo contrario) e incluso sueros fetales importados de empresas de reconocida prestancia con la especificación de ser libres de gérmenes patógenos (incluido el VDVB) nos motivó para realizar el presente estudio. De los 32 lotes de SFB evaluados, fueron positivos a la cepa no citopatogénica del virus el 25.8\%: de 14 lotes de SFB, obtenidos y procesados por la línea de Enfermedades de la Reproducción, resultó 1 lote $(7.14 \%)$ positivo al VDVB; de 16 lotes provenientes de otro laboratorio de Investigación Nacional en SaludHumana, 6 lotes $(37.5 \%)$ fueron positivos al virus. 
Dos de los SFB de origen comercial fueron procesados en el PRA-UNAL: uno fue positivo al VDVB (procedente de USA) y el otro (suero nacional) no pudo procesarse para las pruebas de Virología, por la alta contaminación bacteriana que presentó en la prueba inicial de esterilidad. (Tabla 1).

\begin{tabular}{|lccccc|}
\hline \multicolumn{5}{|c|}{ TABLA 1 } \\
\multicolumn{7}{|c|}{$\begin{array}{c}\text { Detección del VDVB en suero fetal bovino mediante la de } \\
\text { inmunofluorescencia indirecta. (PRA-UNAL) }\end{array}$} \\
\hline Fuente & No.Lotes & $\begin{array}{c}\text { Positivos } \\
\text { No } \%\end{array}$ & $\begin{array}{c}\text { Negativos } \\
\text { No }\end{array}$ & $\%$ \\
\hline Virología (PRA) & 14 & 1 & 7.14 & 13 & 92.8 \\
Lab. (Salud Humana) & 16 & 6 & 37.5 & 10 & 62.5 \\
Comercial Nal. & 1 & 1 & 100 & 0 & 0 \\
Comercial Extranj. & 1 & & N.E. & - & - \\
\hline TOTAL & 32 & 8 & 25.8 & 23 & 74.2 \\
\hline N.E. Sin evaluar por contaminación bacteriana. & & & & & \\
\hline
\end{tabular}

También se realizó la prueba de seroneutralización para evaluar los niveles de anticuerpos al VDVB, siendo negativos los SFB obtenidos por los dos laboratorios de investigación. De los 28 lotes de cultivos celulares evaluados para el VDVB por IFI, fueron 12 muestras positivas, que corresponden al 42.8\%. (Tabla 2 ).

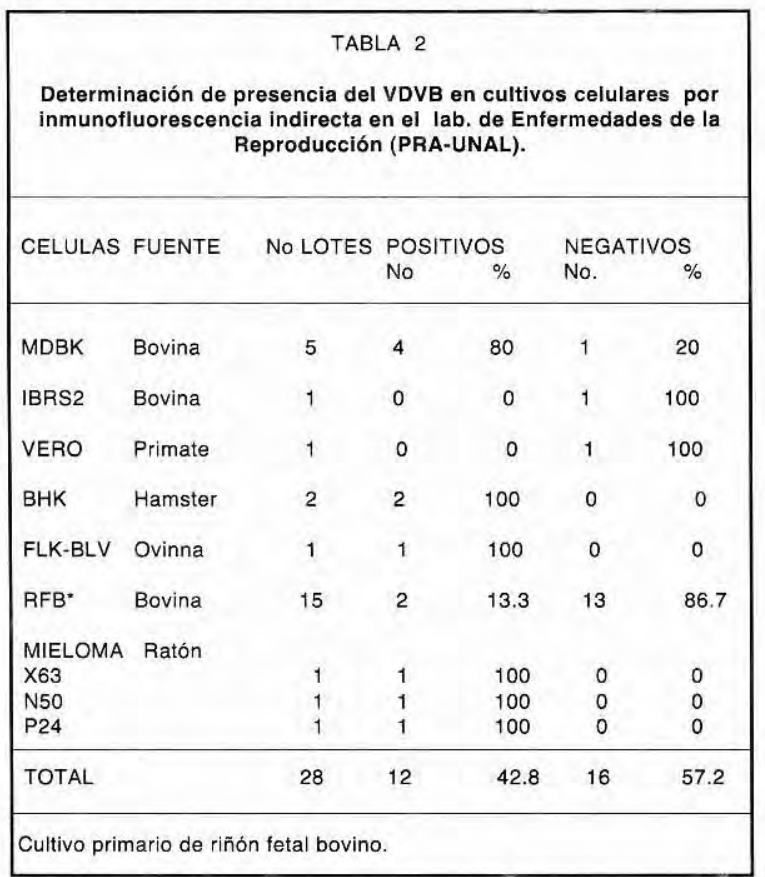

\section{DISCUSION}

El desarrollo de la Virología, ha implicado también un avance en la preparación de cultivos celulares, reactivo biológico necesario para el crecimiento, desarrolloyevaluación de infectividad viral, así como en la producción de biológicos para el control de enfermedades transmisibles.

La suplementación de casi todos los cultivos celulares con suero fetal bovino, incluso de cultivos como los de hibridomas, al igual que la utilización de cultivos primarios provenientes de órganos fetales bovinos; han creado un potencial problema por el empleo de fetos bovinos (suero fetal y células) infectados con el VDVB.

En adición a lo anterior, el suero fetal bovino puede contener anticuerpos contra el VDVB, que interfieren con el aislamiento del virus o dar resultados de falsos positivos en las pruebas serológicas o en las inmunocitoquímicas, (sin establecerse si su presencia en cultivos y líneas celulares de origen humano, tenga o no implicaciones). (5).

Las altas prevalencias serológicas reportadas de la enfermedad, han hecho que el suero fetal bovino (SFB) usado como suplemento para los cultivos celulares, sea un potencial riesgo de contaminación con los biotipos no citopatogénicos del VDVB, convirtiéndose en un problema para todos los laboratorios que emplean SFB.

Con relación a los resultados obtenidos con el SFB, El 7.14\% de positividad al VDVB obtenido por el grupo de investigación del PRA, pudo estar determinado por la selección de fetos provenientes deáreas con baja reactividad serológica y porque cada lote corresponde (en la mayoría de los casos) al suero fetal de sólo 5 animales, en contraposición con los SFB empleados por el otro laboratorio de investigación nacional que son obtenidos a través de la compra a proveedores comerciales.

En lo que respecta a la contaminación en cultivos celulares, tan sólo 1 cepa de células de la línea MDBK traída directamente de la A.T.C.C. USA, (centro de referencia), fue negativa del total de 5 cepas deéstalínea examinada, para una positividad del 80\%; una cepa de la línea FLK-BLV utilizada en la producción de antígeno para diagnóstico de leucosis bovina, también resultó positiva al VDVB. 
Igualmente tres cultivos de células del mieloma, fueron positivas al VDVB; se realizaron 15 cultivos primarios con dos positivos (13.3\%). Evaluaciones de otros cultivos se pueden ver en tabla 2. Los resultados obtenidos por el PRA, tuvieron concordancia con los obtenidos por Bolin y col (6), en lotes SFB producidos especificamente para el National Animal Diseases Laboratory (NADL) (USA) y en lotes de suero fetal de disponibilidad comercial, evaluados también por ellos. De 1608 lotes obtenidos por el NADL 332 (20.6\%) fueron positivos al VDVB así como 93 de 190 (49\%) de los lotes comerciales, evaluados por el NADL (Tabla 3 ).

\begin{tabular}{|lccc|}
\hline \multicolumn{5}{|c|}{ TABLA 3 } \\
DISTRIBUCION DE VDVB Y ANTICUERPOS CONTRA VDVB EN \\
SUERO FETAL BOVINO EN EL NADL (USO)
\end{tabular}

Igualmente, de los lotes obtenidos para NADL se detectó el $14 \%$ con anticuerpos al VDVB por seroneutralización e inmunoperoxidasa.

La calidad del suero fetal bovino empleado en el trabajo de laboratorio, en especial con relación al virus de la DVB, es algo que debe inquietar a la comunidad científica y a los laboratorios productores de biológicos por el riesgo significante que se da en la investigación y en la industria, con virus adventicios como el VDVB.

Con los hallazgos obtenidos por los dos centros de investigación (NADL y PRA-UNAL) comparados en el presente trabajo, se puede estimar que tanto en nuestro medio como en países desarrollados, las contaminaciones de substratos biológicos no son sólo un riesgo sino un problema presente, del cual participan principalmente aquellos laboratorios que por alguna razón no obtienen, procesan y evalúan, su propio SFB. Lo anterior lleva a suponer que existen inconsistencias en las metodologías empleadas para la evaluación del suero fetal bovino, tanto a nivel nacional como internacional.

A pesar de que los sueros comerciales en los Estados Unidos son procesados de acuerdo con las pruebas descritas en el código de Regulaciones Federales, el aislamiento del virus del $49 \%$ en lotes comerciales, indica que existen dificultades con esta metodología. En nuestro medio, sólo algunos institutos de caracter oficial están en capacidad de realizar estas pruebas.

Bolin y col. (6), a diferencia de los controles mencionados por el código de Regulaciones Federales, utilizan un mayor volumen de suero y lo inoculan en botellas rotantes con el fin de garantizar un mejor contacto del virus con las células y la subsecuente infección viral de las mismas. En la determinación de la presencia del VDVB en los cultivos celulares, es importante enfatizar que los cultivos infectados no pueden ser detectados si no se emplean técnicas inmunoquímicas, comola inmunofluorecencia la peroxidasa, debido a que estas dos técnicas detectan la presencia del biotipo no citopático, en los mencionados cultivos.

La seroneutralización y la inmunoperoxidasa, son pruebas que pueden ser empleadas para detectar anticuerpos contra el VDVB, la primera de ellas identifica una glicoproteina (gp53) con muchos sitios antigénicos, la segunda además de la anterior glicoproteina, detecta proteinas virales no implicadas en la seroneutralización y de mayor peso molecular que clásicamente identifican los dos biotipos del virus. La anterior diferenciación se hace mediante la prueba de Inmunoprecipitación en la cual un suero que contenga anticuerpos contra el virus es usado para identificar polipeptidos radiomarcados a partir de un extracto de cultivo celular infectado, aclarando de esta manera el porqué sueros negativos a la prueba de seroneutralización pueden ser positivos a la radioinmunoprecipitación $(6,7)$

\section{SUMMARY}

The Bovine Viral Diarrhoea Virus (BVDV) belongs to the genus Pestisvirus. It is the cause or reproductive disorders in catlle and is widespread in the conuntry. There are noncytophatogenic strains of the BVDV very difficult to detect in the primary tissue culture and cell lines, ordinarilly used in diagnostic test or research activities. Foetal calf serum (FCS) is the common source of contamination for the animal tissue culture, because of the poor quality controll during its collection and markenting 
under local conditions. It is possibly to find two kind of situations related to BVDV and the presence of viral particles; in each case is possible to have problems with the laboratory procedures.

In order to avoid BVDV tissue culture contamination, in our laboratory it has been used an indirect inmunofluorescense technique for the detection of the virus in foetal calf serum and tissue cultures, having results as follows: $28.5 \%$ positives from 32 FCS samples from differnt sources and $42.8 \%$ from tissue cultures from different animal origen and several research centres.

Some recomdations are made for the prevention and control ot this problem at diagnostic and researchlaboratorylevellike the use of IFI, indirect peroxidase techniques, or inmunopresitation for the detection of the virus, and the use of a few number of foetuses for each lot of FCS in order to reduce the risk of contamination from this source.

\section{AGRADECIMIENTOS:}

Los autores agradecen ala Corporación Andina de Fomento (CAF) el apoyo económico brindado para la realización de la presente publicación.

\section{BIBLIOGRAFIA}

1. Duffell MW,Harkness JW. Bovine Virus Diarrhoea-Mucosal Infection in catlle. Vet. Rec. 1985; 117: 240.

2. Baker CJ. Bovine Viral Diarrhoea Virus: A Review: JAVMA. 1987; 90(11): 1449.

3. Collet M,Larson R,Belzer E. Proteins encoded by bovine viral diarrhoea virus: The genomic organtization of a pestisvirus. Virology. 1988; 165: 220.

4. Corapi WV, Donis RO, Dubovi EJ. Monoclonal antibody analyses of cytopathic and Noncytopathic Viruses from total Bovine Viral Diarrhoea Virus Infections. Journal of Virology. $1988 ; 2823$.

5. Hassan A,Scott G. A technique to obviate the risk of inadvertent infection of cell cultures with bovine viral diarrhoea virus. J Com Pathol. 1986; 96: 241.

6. Bolin S, Matthews P, Ridpath J. Methdos for detection of contamination an frecuency of contamination of fetal calf serum with bovine viral diarrhoe 3 a virus and antibodies against bovine viral diarrhoea virus. Un published. 1991.

7. Dubovi EJ. Molecular biology of bovine virus diarrhoea virus. Rev Sci Tesch Off int epiz. 1190; 9(1): 105. 